\title{
Development of Competence in Cultures of Bacillus subtilis Inoculated with Different Numbers of Bacteria
}

\author{
By S. HORVÁTH \\ Institute of Genetics of the Hungarian Academy of Sciences, Budapest
}

(Accepted for publication 8 March 1967 )

SUMMARY

The influence of casein hydrolysate, tryptophan, glucose, magnesium sulphate and different buffer solutions on the rate of multiplication of Bacillus subtilis strain 168 was determined. Inoculum size was shown to influence the generation time and the increase in the mass of bacteria was found to be inversely proportional to the size of the inoculum.

Bacillus subtilis 168 forms chains especially in minimal media. In complete media chains are formed by only a small proportion of the bacteria and sometimes not at all.

A simple transformation method was used to follow the development of competence in cultures of Bacillus subtilis 168 in media inoculated with different numbers of bacteria.

The estimation of the number of transformants was subject to greater error than estimation of the viable count.

This error in the estimation of the number of transformants is due mainly to the thread-like character of DNA, which is difficult to dilute accurately. The smaller the inoculum of bacteria, the shorter the time for the rise phase of competence. Optimal competence is reached when about $10^{6} \mathrm{bacteria} / \mathrm{ml}$. are inoculated into the medium.

The rise phase of competence takes a shorter time than the decline phase.

An equation was developed from which it is easy to calculate approximately the onset of the peak of competence. Precise determination of this peak can be achieved by controlling the density of the bacterial suspension.

\section{INTRODUCTION}

Genetic transformation has been demonstrated in: Streptococcus pneumoniae (Hotchkiss, 1957); Haemophilus influenzae (Goodgal \& Herriott, 196I); Neisseria meningitidis (Alexander \& Redman, 1953); N. catarrhalis (Catlin \& Cunningham, 1964); Agrobacterium (Klein \& Klein, 1953); Xanthomonas (Corey \& Starr, 1957); Rhizobium (Balassa, 1954; Balassa, 1960); Streptococcus (Bracco, Krauss, Roe \& MacLeod, 1957); and in Bacillus subtilis (Spizizen, 1958). DNA isolated from donor bacteria is taken up by the recipient organisms during the physiological state known as competence.

From the literature concerning competence it is apparent that several investigators have found different optimal conditions for transformation (Jensen \& Haas, 1963; Ephrussi-Taylor \& Freed, 1964; Tomasz, 1965). It seems that the factors influencing transformation are not completely known.

Competent bacteria can be transformed by DNA isolated from donor bacteria. DNA from bacteriophage (Földes \& Trautner, I964; Harm \& Rupert, 1963) and 
virus (Abel \& Trautner, 1964; Bayreuther \& Romig, 1964) can be incorporated into competent bacteria and can replicate in them. Competence is therefore an important field of investigation.

In media inoculated with a small number of Bacillus subtilis I68, (Burkholder \& Giles 1947) we found that the organisms divided more times than when the medium was inoculated with a large number of bacteria. Of course, the increase in the mass of bacteria was also greater in media inoculated with a smaller number of bacteria. Their evidence also suggested that there were differences in generation time for bacteria in cultures inoculated with different numbers of organisms. These changes in generation time were of interest to us because it seemed that they may play an important part in the development of competence.

Therefore experiments were carried out to investigate in detail the relationship between generation time and the development of competence.

\section{METHODS}

Bacterial strains. For transformation the recipient strain Bacillus subtilis 168 try-, and the donor strain B. subtilis MARBURG were both kindly provided by Dr B. S. Strauss. (See Burkholder \& Giles, 1947; Spizizen, 1958; Nester, 1964).

Media. (a). Bacterial strains were maintained on potato agar (Spizizen, 1958; Nester, I964).

(b) Minimal glucose yeast agar medium (MGY agar): $0.2 \%\left(\mathrm{NH}_{4}\right)_{2} \mathrm{SO}_{4}, \mathrm{I} \cdot 4 \%$ (w/v) $\mathrm{K}_{2} \mathrm{HPO}_{4}, 0.6 \% \mathrm{KH}_{2} \mathrm{PO}_{4}, 0 . \mathrm{I} \% \mathrm{Na}$-citrate. $2 \mathrm{H}_{2} \mathrm{O}, 0.02 \% \mathrm{MgSO}_{4} .7 \mathrm{H}_{2} \mathrm{O}, 0.5 \%$ glucose, $5 \mu \mathrm{g} . / \mathrm{ml}$. L-tryptophan, $0.1 \%$ casein hydrolysate (Difco), $0.2 \%$ yeast extract (Difco), and $\mathrm{I} \cdot 75 \%$ (w/v) agar.

(c) The development of competence was investigated in MGY liquid medium.

(d) T-medium was used for transformation: $\mathrm{I} \cdot 4 \%$ (w/v) $\mathrm{K}_{2} \mathrm{HPO}_{4}, 0.6 \% \mathrm{KH}_{2} \mathrm{PO}_{4}$, $0.5 \%$ glucose, $0.1 \%$ casein hydrolysate, $2.5 \mu \mathrm{g} . / \mathrm{ml}$. L-tryptophan and $5 \mu \mathrm{moles} / \mathrm{ml}$. $\mathrm{MgSO}_{4} \cdot 7 \mathrm{H}_{2} \mathrm{O}$.

(e) MG agar: MGY agar without L-tryptophan and yeast extract, containing $0.02 \%$ casein hydrolysate was used for the selection of transformants.

Chain formation. Smears of the bacteria were made, fixed and stained with gentian violet for $2 \mathrm{~min}$. and examined by the light microscope. The results were analysed statistically by expressing the number of bacteria per chain in log to the base 2 units since chain lengths were related by a factor of two.

Preparation of transforming DNA. $10^{7}$ organisms of Bacillus subtilis Marburg grown in log. phase were inoculated into $250 \mathrm{ml}$. MGY medium without tryptophan in four I 1. Erlenmeyer flasks and incubated at $30^{\circ}$ for $15 \mathrm{hr}$. with mechanical shaking. When the cultures contained about $10^{9}$ bacilli $/ \mathrm{ml}$., the suspensions were centrifuged and DNA was isolated by the phenol extraction method of Saito \& Miura (1963).

Determination of competence. Bacteria from potato agar were inoculated onto MGY agar slopes and incubated for $16 \mathrm{hr}$ at $37^{\circ}$. The growth was scraped off, suspended in MGY nutrient medium and adjusted to a suitable optical density: $10 \mathrm{ml}$. of this suspension were measured into $100 \mathrm{ml}$. Erlenmeyer flasks fitted with side arms for optical density measurements. The bacterial suspensions were incubated in a water bath at $37^{\circ}$ on a reciprocal shaker at $100 \mathrm{rev} . / \mathrm{min}$.

During growth, samples were taken and assayed for the number of competent 
bacteria by measuring the efficiency of transformation to prototrophy under standard conditions.

Transformation procedure. The samples were adjusted with T-medium to $0 \cdot 1$ optical density (equivalent to $5.9 \times 10^{7}$ colony forming units $/ \mathrm{ml}$.). To $0.25 \mathrm{ml}$. of this suspension $0.75 \mathrm{ml}$. of DNA solution in T-medium was added to give a final concentration of DNA about $\mathrm{I} \mu \mathrm{g} . / \mathrm{ml}$.

This mixture was shaken for $15 \mathrm{~min}$. in a water bath at $37^{\circ}$ and $0.2 \mathrm{ml}$. was then plated on MG agar about I or $2 \mathrm{~cm}$. from the edge of the Petri dish. The dish was. kept on an inclined plane and gently shaken to distribute the suspension over the agar surface, avoiding the use of a glass spreader. This procedure took $10-15 \mathrm{sec}$. The surface of the plates inoculated in such a way was dried off at $37^{\circ}$ for $20-25 \mathrm{~min}$. The final dilution of the bacterial suspension was at least $\mathrm{I} / 1500$ at which dilution the final concentrations of tryptophan and yeast extract from the inoculum were not sufficient to permit the growth of the recipient Bacillus subtilis I68 try- strain. Only prototrophic try ${ }^{+}$transformants could grow; the number of such transformants was counted on the following day.

\section{RESULTS}

The effect of casein hydrolysate, tryptophan and pHon the growth of Bacillus subtilis 168.

Since it has been suggested that casein hydrolysate plays an essential role in the development of competence in Bacillus subtilis (Anagnostopoulos \& Spizizen, 196I), the effects of various concentrations of casein hydrolysate on the growth of $B$. subtilis were investigated. Optical density measurements on cultures after $8 \mathrm{hr}$ growth in casein hydrolysate show that the lag phase is shorter and the log rise steeper in high concentrations of casein hydrolysate compared to low concentrations (Fig. I).

$5 \mu \mathrm{g} . / \mathrm{ml}$. L-tryptophan was sufficient to give maximum growth of Bacillus subtilis 168 try ${ }^{-}$and the density of cultures did not change until the tryptophan concentration exceeded $80 \mu \mathrm{g}$. $/ \mathrm{ml}$. Glucose and $\mathrm{MgSO}_{4} \cdot 7 \mathrm{H}_{2} \mathrm{O}$ had very little or no effect on the growth of $B$. subtilis. Nutrient media containing $0.02 \%$ casein hydrolysate, $0.5 \%$ glucose and $50 \mu \mathrm{g} . / \mathrm{ml}$. L-tryptophan and buffered with phosphate at different $\mathrm{pH}$ values from 5.59 to 8.04 were used for the cultivation of Bacillus subtilis 168. Optimal multiplication of the bacteria was found in nutrient medium at $\mathrm{pH} 6 \cdot 8-7 \cdot 0$.

\section{The effect of inoculum size on the growth of Bacillus subtilis}

To test the effect of inoculum size on the growth of Bacillus subtilis different numbers. of bacteria were seeded into media containing $0.5 \%$ glucose, $0.04 \%$ casein hydrolysate, $5 \mu \mathrm{g} / \mathrm{ml}$. L-tryptophan and $80 \%(\mathrm{v} / \mathrm{v}) \mathrm{M} / 20$ tris- $\mathrm{HCl}$ buffer at $\mathrm{pH} 7 \cdot \mathrm{I}$. Incubation was continued for Io $\mathrm{hr}$ and the growth curves obtained are shown in Fig. 2.

The biggest increase in bacterial mass was found when the lowest numbers of bacteria $\left(2 \cdot 95 \times 10^{6}\right)$ were inoculated into the medium (Fig. 3). The data also show that the bacteria had to divide at least four times in the case of the smallest inoculum, and only once in the case of the largest one. These results are in agreement with the estimates of division made from the lengths of the bacterial chains found during cultivation.

The changes in the generation times of these bacteria were determined from the growth curves obtained in this same experiment and are shown in Fig. 4. This figure 
shows clearly that there are big differences in generation time for bacteria in cultures grown from different sized inocula.

\section{Chain formation by Bacillus subtilis}

We paid special attention to chain formation because B. subtilis 168 forms long chains under certain conditions. To obtain accurate colony counts in transformation experiments therefore it is important to use suspensions of single bacteria. In liquid MGY nutrient meduim chains increased up to the beginning of the log. phase, but thereafter single bacteria were produced (Fig. 5). Colony counts give an accurate estimate of the numbers of viable bacteria in these suspensions.

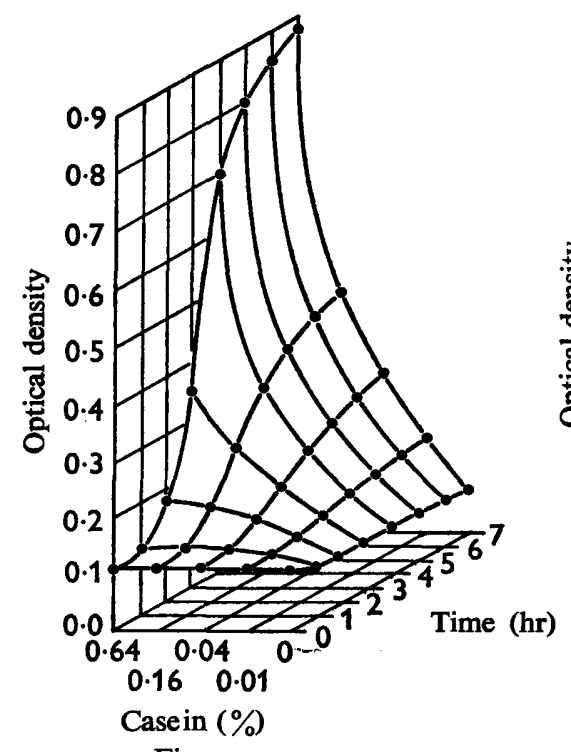

Fig. I

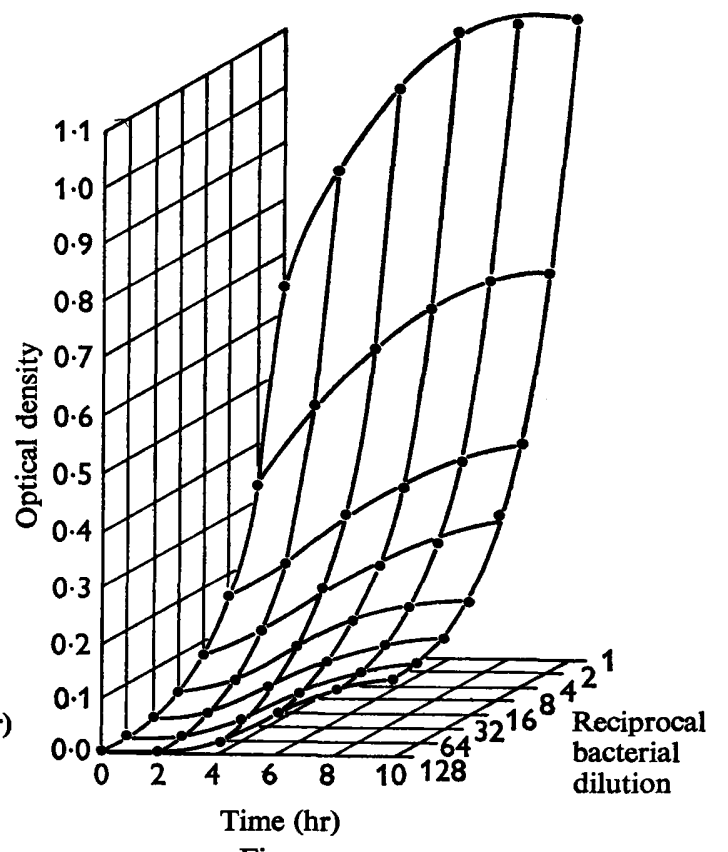

Fig. 2

Fig. I. Growth curve of Bacillus subtilis in $80 \%(\mathrm{v} / \mathrm{v})$ tris- $\mathrm{HCl}$ buffer at $\mathrm{pH} 7 \cdot \mathrm{I}, 0.5 \%(\mathrm{w} / \mathrm{v})$ glucose, $5 \mu \mathrm{g} . / \mathrm{ml}$. L-tryptophan and various concentrations of casein hydrolysate.

Fig. 2. The effect of inoculum size on the growth of Bacillus subtilis in $80 \%(\mathrm{v} / \mathrm{v})$ tris-HCl buffer at pH $7 . \mathrm{I}$ containing $0.5 \%(\mathrm{w} / \mathrm{v})$ glucose, $0.04 \%$ casein hydrolysate and $5 \mu \mathrm{g} . / \mathrm{ml}$. tryptophan. The medium was inoculated from serial twofold dilutions of a suspension of $3.8 \times 10^{8}$ bacteria $/ \mathrm{ml}$.

\section{Transformation procedure}

DNAse was not used after the 15 min. incubation period with DNA. If the transformation system does not contain tryptophan, transformants do not appear. This was demonstrated by the following experiment.

To samples of T-medium, containing different quantities of tryptophan and $2 \mu \mathrm{g}$. DNA/ml., equal volumes of bacterial suspensions ( 0.2 optical density units) in Tmedium without tryptophan were added. These suspensions were shaken for $15 \mathrm{~min}$. at $37^{\circ}$ and plated on MG agar for the recovery of transformants. The results are illustrated in Fig. 6. It appears that transformation does not occur in media containing very 
small amounts of tryptophan. Plating slowly stops further transformations, because the tryptophan became diluted. In control experiments in which the bacterial suspension did not contain any DNA, try ${ }^{+}$colonies were not found at tryptophan concentra-

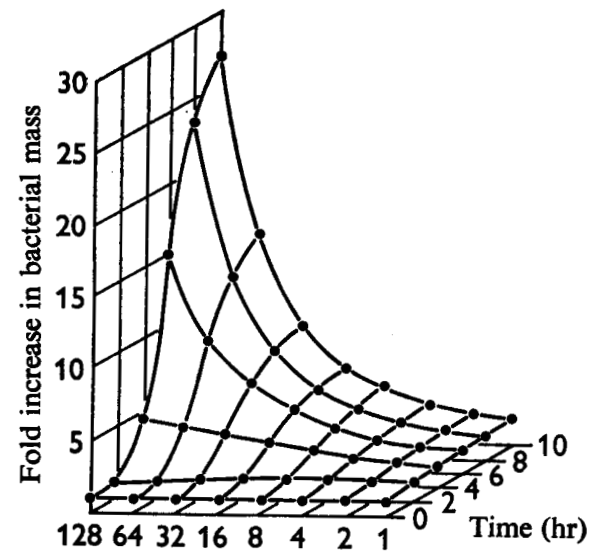

Bacterial (reciprocal) dilution

Fig. 3

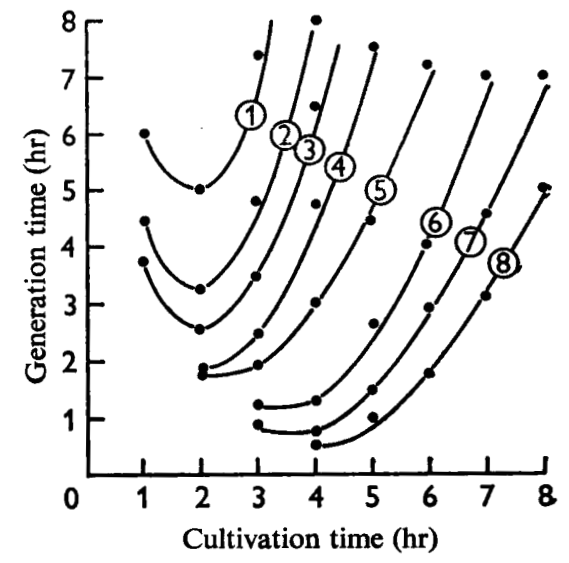

Fig. 4

Fig. 3. Increase in the bacterial mass of Bacillus subtilis cultures started from different inocula calculated from the data in Fig. 2.

Fig. 4. Changes in the generation time of Bacillus subtilis in cultures started from different inocula calculated from the growth curves in Fig. 2.

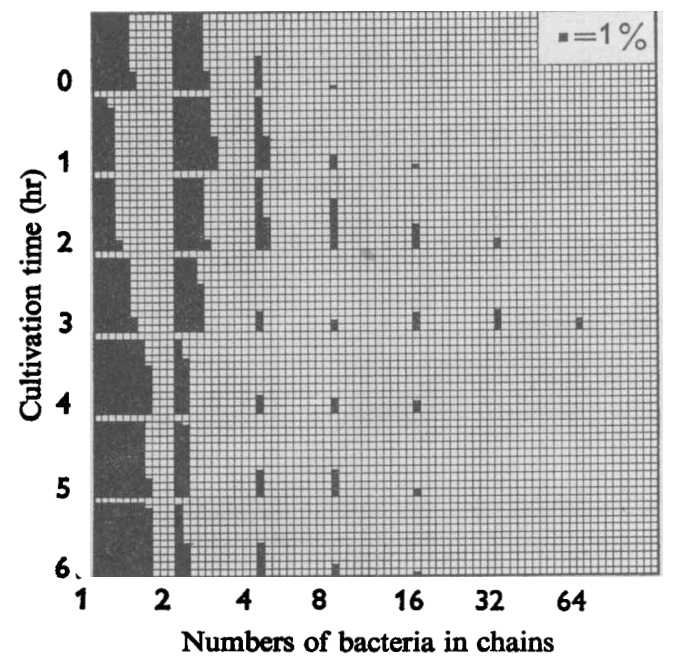

Fig. 5

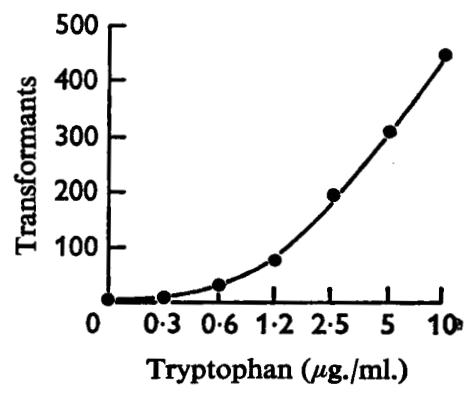

Fig. 6

Fig. 5. Percentage distribution of chain length in $6 \mathrm{hr}$ cultures of Bacillus subtilis. The bacteria were grown in MGY nutrient medium.

Fig. 6. The effect of various concentrations of tryptophan on the jyield of try transformants. from Bacillus subtilis 168 try-. 
tions up to Io $\mu \mathrm{g}$. $/ \mathrm{ml}$. For this reason $2.5 \mu \mathrm{g}$. tryptophan $/ \mathrm{ml}$. was used in T-medium for transformation.

The thread-like nature and viscosity of the DNA make it very difficult to dilute accurately, and even after diluting with great care the numbers of transformants vary greatly in parallel experiments. To determine this error $0.75 \mathrm{ml}$. of DNA diluted in T-medium was measured into each of 20 tubes and $0.25 \mathrm{ml}$. of a competent cell suspension ( $O \cdot I$ optical density units) added to each tube. The final concentration of DNA was I $\mu \mathrm{g} . / \mathrm{ml}$. After incubation the mixture was plated out on MG agar for recovery of transformants. The average number of transformants per plate was 146 with a standard deviation of \pm 85 .

Viable counts were determined on 27 samples from the same suspension. The average number of colonies per plate was 100 with a standard deviation of \pm 23 . These results show that in estimating the number of transformants there are greater errors than in estimating the number of viable bacteria. If there are chains of bacteria the accuracy of the viable count will be even less.

\section{Determination of the time of development of competence}

A bacterial suspension was inoculated into MGY medium at $0 \cdot 1$ optical density units and incubated at $37^{\circ}$. At regular intervals samples were moved and the competence of the culture assayed by measuring the number of transformants obtained by the standard transformation procedure.

The development of competence is shown in Fig. 7 together with the changes in the generation times of the bacteria in these cultures. The shaded area of the figure represents the results obtained from 75 samples. It is clear that there was some regularity in the development of competence and that it was related to the changes in generation time. Three phases can be differentiated in the development of competence, the 'silent' phase (Fig. $7 \mathrm{~A}, \mathrm{~B}$ ), the 'rise' phase (Fig. 7 B, C) and the 'decline' phase (Fig. ${ }_{7} \mathrm{C}, \mathrm{D}$ ). The most interesting points are $\mathrm{B}$, the beginning, and $\mathrm{C}$, the peak of competence.

The steepness of the rise phase of competence was characterized by the time which was necessary to obtain a twofold increase in competence. This value can be calculated from the following equation:

where

$$
C_{i}=t / N,
$$

$C_{i}=$ the twofold increase of competence in min.

$t=$ the time of the rise phase of competence in min.

$N=$ the number of transformants at the peak of competence in log. to the base 2 units.

In all the experiments the rise periods of competence were not quite straight lines on a semilogarithmic plot, but slightly curved. This clearly shows that more than one factor influences competence.

The development of competence in cultures inoculated with different numbers of bacteria

Different numbers of bacteria were inoculated into MGY medium. The bacterial suspensions were incubated in a water bath at $37^{\circ}$ on a reciprocal shaker. At regular intervals samples were rem oved and adjusted with Y-medium to $0 \cdot 1$ optical density units. To $0.25 \mathrm{ml}$. of this suspension $0.75 \mathrm{ml}$. DNA solution was added; the final 
concentration of DNA was about I $\mu \mathrm{g} . / \mathrm{ml}$. This mixture was shaken for $15 \mathrm{~min}$. at $37^{\circ}$ and $0.2 \mathrm{ml}$. was then plated on MG agar for transformation. Figure 8 shows the changes in optical density and the shaded area of the figure shows the rise phase of competence. From this experiment the generation times were determined and results in Fig. 9 show that the smaller the inoculum of bacteria, the shorter the time for the

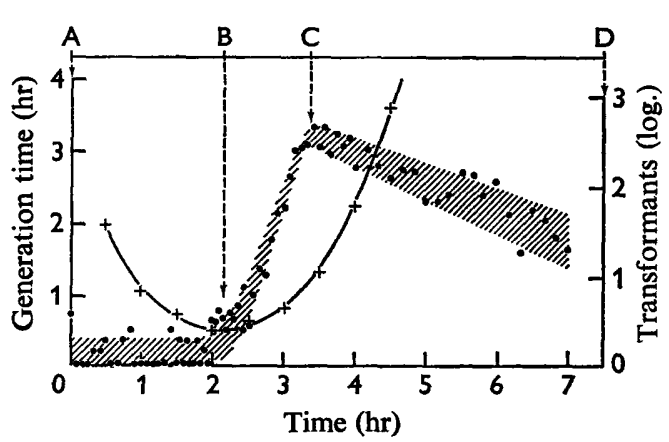

Fig. 7

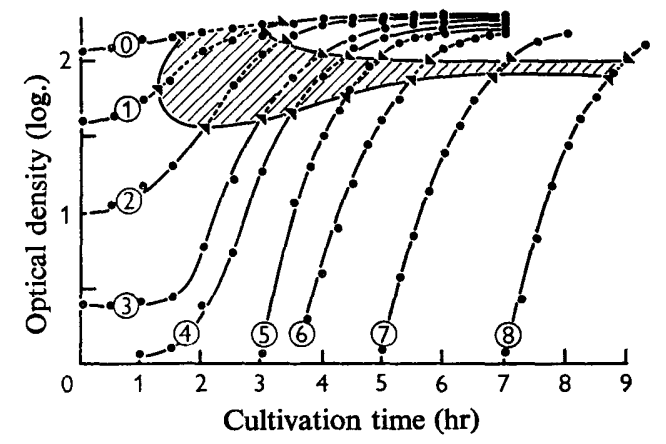

Fig. 8

Fig. 7. Changes in generation time and the development of competence in cultures of Bacillus subtilis 168 try $^{-}$. The shaded area represents the development of competence. Fig. 8. Changes in optical density and the development of competence in cultures of Bacillus subtilis 168 try $y^{-}$inoculated with different numbers of bacteria. Bacteria/ml. at the start of the culture: curve $0,6.93 \times 10^{8}$; curve $1,2.35 \times 10^{8}$; curve $2,5.90 \times 10^{7}$; curve $3,1.49 \times 10^{7}$; curve $4,3.72 \times 10^{8}$; curve $5,9.35 \times 10^{5}$; curve $6,1 \cdot 18 \times 10^{5} ;$ curve $7,7 \cdot 45 \times 10^{3} ;$ curve $8,1 \cdot 00 \times$ $10^{2}$. The shaded area represents the rise phase of competence.

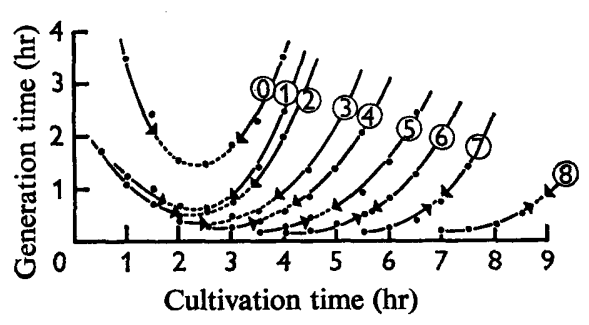

Fig. 9

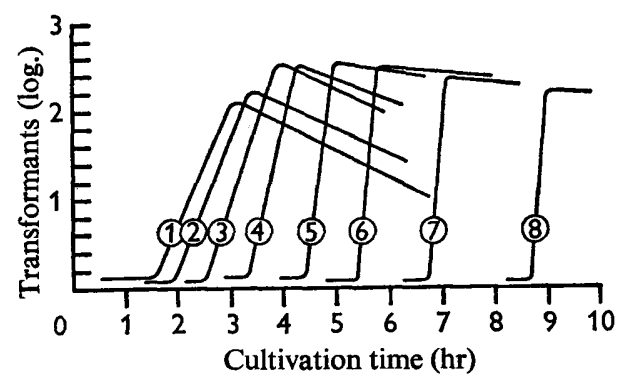

Fig. Io

Fig. 9. The changes in generation time and rise phase of competence in cultures of Bacillus subtilis 168 try-inoculated with different numbers of bacteria. The dotted line represents the rise phase of competence. For details of inocula see Fig. 8.

Fig. 10. Development of competence in cultures of Bacillus subtilis 168 try- inoculated with different numbers of bacteria. For details of inocula see Fig. 8.

rise phase of competence. The generation time was about $45-60 \mathrm{~min}$. except for the culture with the largest inoculum. Nester also found that optimal competence was obtained for cultures with a generation time of about $45 \mathrm{~min}$. (Spizizen, 1958).

Curves showing the development of competence in cultures from this experiment are shown in Fig. 10. The rise phase of competence was steep and appeared late in 
cultures inoculated with a small quantity of bacteria. The time which was necessary for a twofold increase in competence in cultures inoculated with different numbers of bacteria is shown in Fig. I I ; it was very short for cultures started with a small inoculum of bacteria. The numbers of transformants scored at the peaks of competence are also given in Fig. II. Optimal competence appeared when about $10^{6}$ bacteria $/ \mathrm{ml}$. were inoculated at the beginning of the experiment. The number of transformants obtained during the rise phase of competence is shown in Fig. 12, as \% of the total.

The rise phase of competence is shown in Fig. I3 for cultures started with different bacterial inocula. The upper line connecting the peaks of competence is straight; except for cultures inoculated with a very large number of bacteria, it was calculated by the least square method.

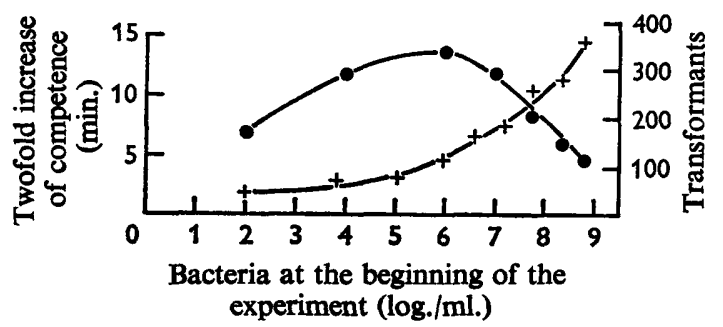

Fig. I I

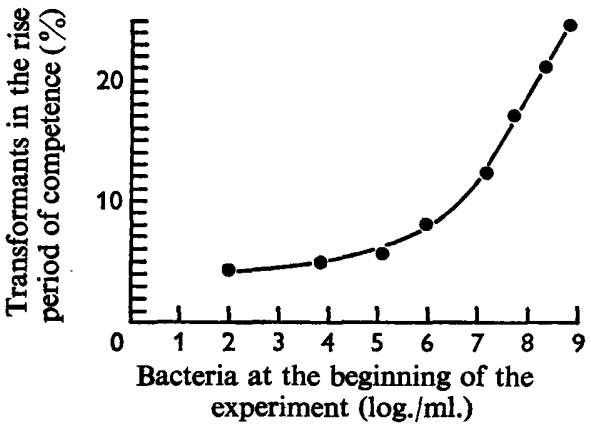

Fig. 12

Fig. II. The time required for a twofold increase in competence and the number of transformants at the peak of competence for cultures of Bacillus subtilis 168 try-inoculated with different numbers of bacteria. +-+ , increase in competence; $-\infty$, number of transformants.

Fig. 12. The number of transformants in the rise phase of competence expressed as a percentage of the total number of transformants for cultures of Bacillus subtilis 168 try $^{-}$ inoculated with different numbers of bacteria.

On the basis of simple considerations an equation was developed from which it is easy to calculate approximately the time necessary to obtain optimal competence in a culture:

where

$$
C_{p}=(a-b) \cdot \operatorname{tg} \alpha,
$$

$C_{p}=$ the time of incubation in $\mathrm{hr}$ to reach the peak in competence.

$a=$ the distance in log. units where the straight line intersects the abscissa (in

Fig. I3 approximately II $\cdot 26$ ),

$b=$ the number of bacteria $/ \mathrm{ml}$. in log. units inoculated into the medium,

$\operatorname{tg} \alpha=$ the tangent of the straight line (in Fig. I3 approximately 0.95).

The values of $a$ and $\operatorname{tg} \alpha$ show some variation in different media, so it is important to standardize experimental conditions in these experiments. But even under standard conditions there is some variation in the time required to reach optimal competence when calculated according to the equation. The higher the inoculum of bacteria the smaller the error. When a small number of bacteria were inoculated, the error was about \pm 5 to Io min. In these circumstances the peak of competence can only be calculated approximately because the rise phase of competence is short-about $15^{-20} \mathrm{~min}$. 
In practice it was easy to determine optimal competence by controlling the optical density of the bacterial suspension. In Fig. I4 the optical density values are shown at the start and at the peaks of competence for cultures inoculated with different numbers of bacteria. The lower curve in Fig. I 4 connects the points at the beginning of competence and the upper curve connects the points at the peaks of competence. Using the upper curve the optimal values of competence can be determined with a deviation of \pm 2 to $3 \mathrm{~min}$.

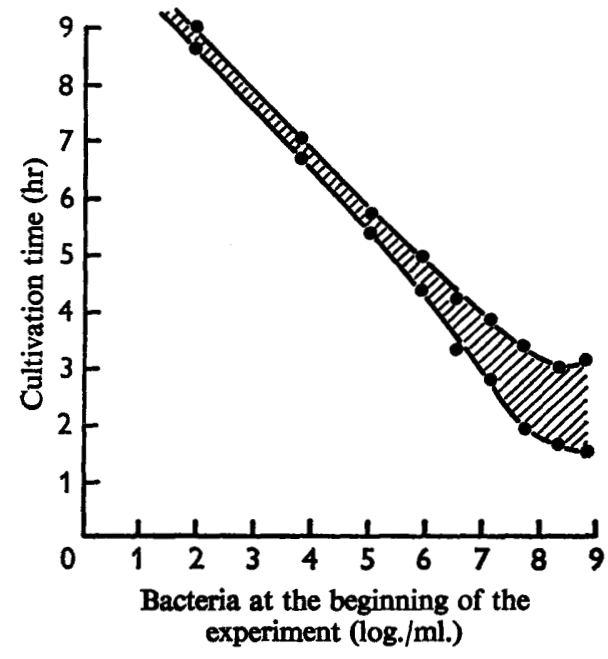

Fig. 13

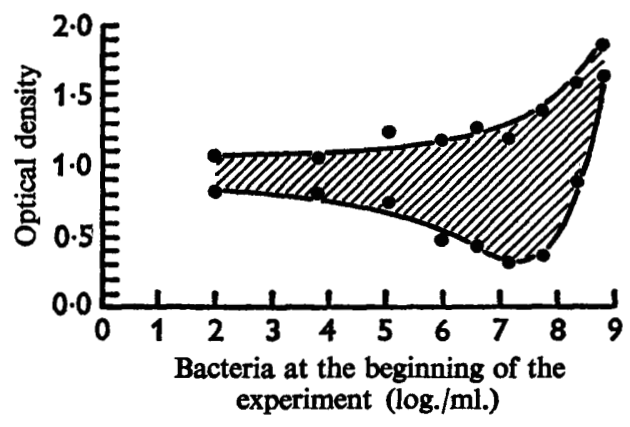

Fig. 14

Fig. 13. Time required to reach the rise phase of competence in cultures of Bacillus subtilis 168 try- inoculated with different numbers of bacteria.

Fig. 14. Optical density values at the start and at the peaks of competence for cultures of Bacillus subtilis inoculated with different numbers of bacteria.

I should like to express my gratitude to Director Dr B. Györffy for his valuable instruction and to I. Kállay for her expert technical assistance.

\section{REFERENCES}

Abel, P. \& Trautner, T. A. (1964). Formation of an animal virus within a bacterium. Z. VererbLehre $95,66$.

AleXANDeR, H. E. \& Redman, W. (1953). Transformation of type specificity of meningococci. Change in heritable type induced by type specific extracts containing desoxyribonucleic acid. J. exp. Med. 97, 797.

ANAGNOSTOPOUlos, C. \& SpIzIZEN, J. (1961). Requirements for transformation in Bacillus subtilis. J. Bact. 8r, 74I.

Balassa, R. (1954). Transformationsmechanismen der Rhizobien. Acta microbiol. hung. 2, 5 I.

BALASSA, R. (1960). Transformation of a strain of Rhizobium lupini. Nature, Lond. 188, 246.

BAYreuther, K. E. \& Romig, W. R. (1964). Polyoma virus: production in Bacillus subtilis. Science, N.Y. I46, 778.

Bracco, R. M., Krauss, M. R., Roe, A. S. \& MacLeod, C. M. (I957). Transformation reactions between pneumococcus and three strains of streptococci. J. exp. Med. 106, 247.

Burkholder, P. R. \& GILES, N. H. (1947). Induced biochemical mutations in Bacillus subtilis. Am. J. Bot. 34, 345. 
Catlin, B. W. \& CunNingham, L. S. (1964). Genetic transformation of Neisseria catarrhalis by deoxyribonucleate preparations having different average base composition. J. gen. Microbiol. 37, 34I.

COREY, R. R. \& STARr, M. P. (1957). Genetic transformation of Neisseria by culture slime containing deoxyribonucleate. Science, N.Y. r3T, 608.

EPHRUSSI-TAYLOR, H. \& Freed, B. A. (1964). Incorporation of thymidine and amino acids into deoxyribonucleic acid and acid-insoluble cell structures in pneumococcal cultures synchronized for competence to transform. J. Bact. 87, 121 I.

Földes, J. \& Trautner, T. A. (1964). Infectious DNA from a newly isolated Bacillus subtilis phage. $Z$. VererbLehre. 95, 57.

Goodgal, S. H. \& Herriott, R. M. (1961). Studies on transformation of Haemophilus influenzae. I. Competence. J. gen. Physiol. 44, 1201.

HARM, W. \& RUPERT, C. S. (1963). Infection of transformable cells of Haemophilus influenzae by bacteriophage and bacteriophage DNA. Z. VererLehre 94, 336.

Hotchkiss, R. D. (1957). Criteria for quantitative genetic transformation of bacteria. In The Chemical Basis of Heredity, p. 321. Baltimore: John Hopkins Press.

Jensen, R. A. \& HAAS, F. L. (1963). Electrokinetics and cell physiology. II. Relationship of surface change to onset of bacterial competence for genetic transformation. J. Bact. 86, 79.

KLEIN, D. T. \& KLEIN, R. M. (1953). Transmittance of tumorinducing ability to avirulent crown-gall and related bacteria. J. Bact. 66, 220.

NeSTER, E. W. (1964). Penicillin resistance of competent cells in deoxyribonucleic acid transformation of Bacillus subtilis. J. Bact. 87, 867.

SaIto, M. \& MrURA, K. I. (1963). Preparation of transforming deoxyribonucleic acid by phenol treatment. Biochim. biophys. Acta 72, 6r9.

SpIzizEN, J. (1958). Transformation of a biochemically deficient strain of Bacillus subtilis by deoxyribonucleate. Proc. natn. Acad. Sci. U.S.A. 44, 1072.

Tomasz, A. (1965). Control of the competent state in Pneumococcus by a hormone like cell product: an example for a new type of regulatory mechanism in bacteria. Science, N.Y. $208,155$. 